German Development Cooperation Pakistan
GTZ International Services Asia

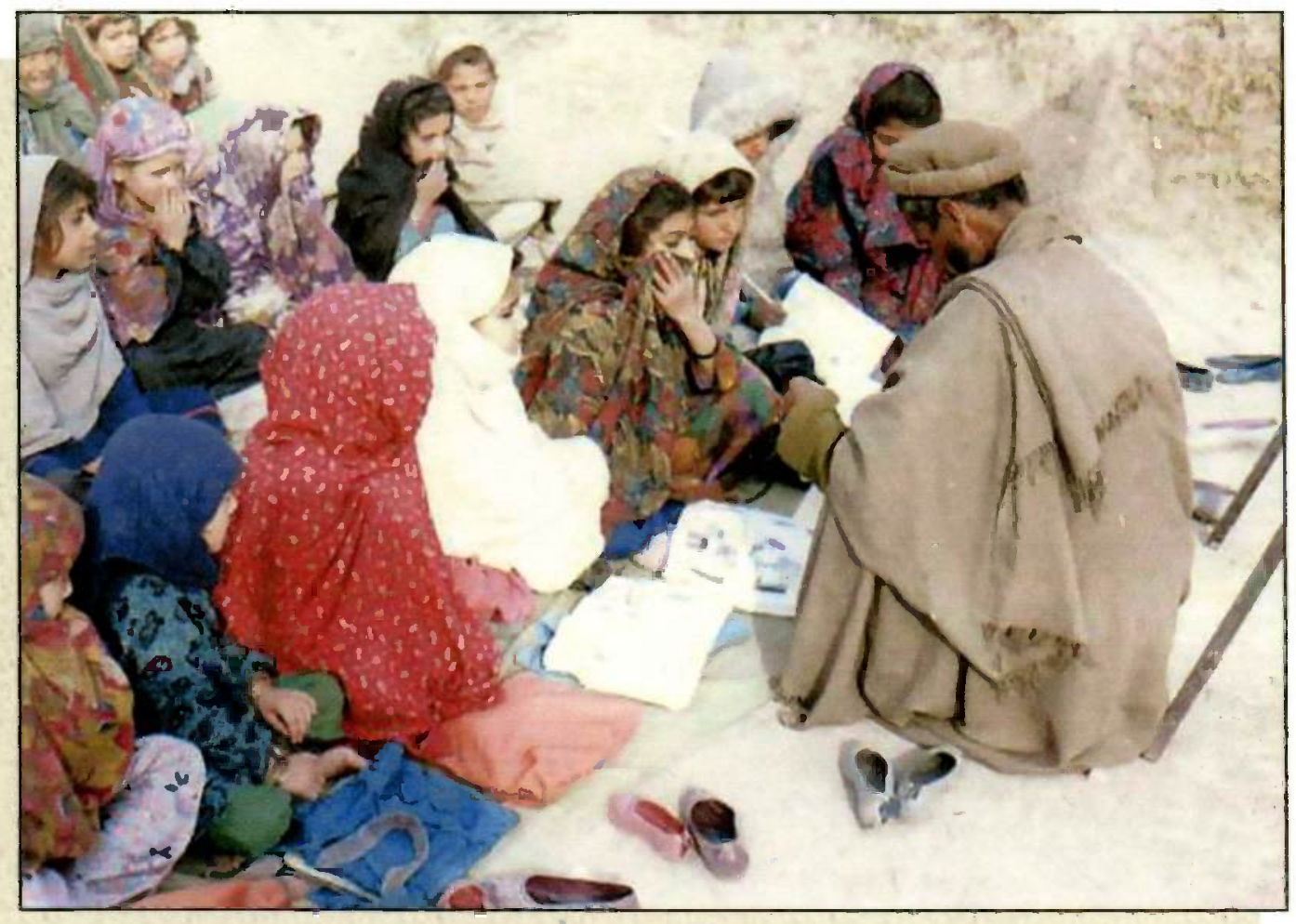

\title{
Basic Education for Afghan Refugees (BEFARe) Pakistan
}
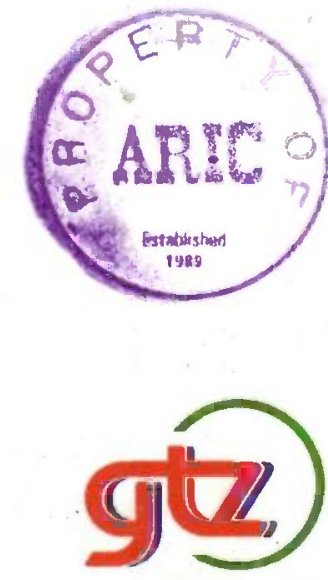

Deutsche Gesellschaft für

Technische Zusammenarbeit (GTZ) GmbH 


\section{GTZ-Specialists in Refugee Education}

\section{BASIC EDUCATION FOR AFGHAN REFUGEES (BEFARe)}

\section{INTRODUCTION AND OFFICIAL STATUS}

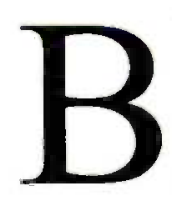

EFARe is a governmental project, being implemented under the bilateral agreement signed on behalf of the Islamic Republic of Pakistan and the Federal Republic of Germany, to provide educational opportunities and assistance to Afghan refugees in the North West Frontier Province (NWFP). It aims at improving basic education for children through formal (primary) education, for both male and female learners, literacy for adults as well as mother and child health for Afghan women. The current project phase runs from $1^{\text {st }}$ January, 1999 to $31^{\text {st }}$ December 2002.

The project is jointly executed by the "Commissionerate for Afghan Refugees" (CAR) and the "German Agency for Technical Cooperation" (GTZ). The central office of the project is located in Peshawar with sub-centers in Bannu, Hangu, Mardan, Timergara and Abbottabad and covers all Afghan refugee camps throughout the North West Frontier Province (NWFP).



Since 1996, BEFARe implements additional basic education activities on behalf of UNHCR. More recent agreements for BEFARe's activities have been signed with DFID and World Bank. Augmentation of the project activities with DFID 
funds started in June 2001. The implementation of activities under the World Bank component have commenced from January 2002.

\section{OBJECTIVES OF BEFARe}

The project is aiming to assist Afghan children and adults, within their own Islamic culture and moral value, which are very important for people who were forced out of their country and who want to maintain their religious and national identity. Thus, the goal of the project is to provide and improve the quality of basic education to refugees and to enhance the basic education system on the basis of community self help.

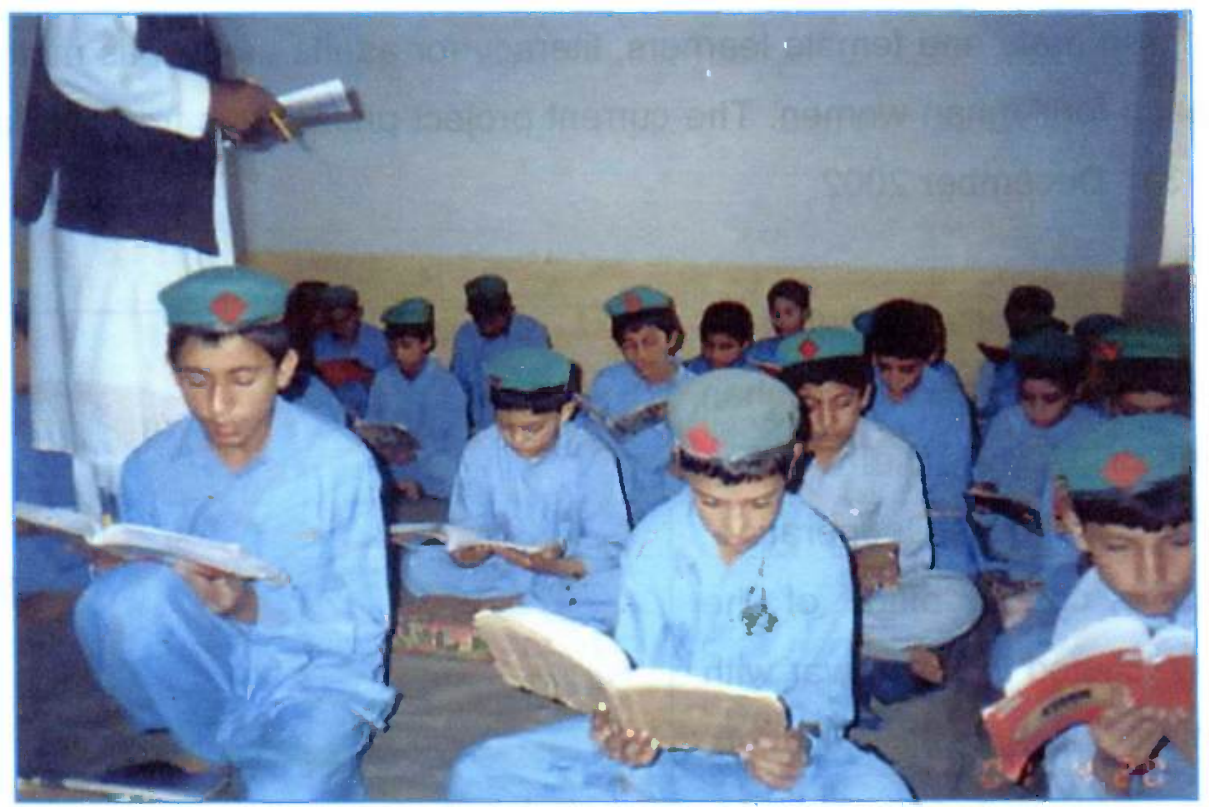

\section{PURPOSE OF THE PROJECT}

The main purpose of the educational project are writing appropriate objectives, suggesting adaptation, modification, improvement and the further development of suitable teaching methods. This includes the preparation of effective teaching materials, improved training methodologies and monitoring practices 
based on a clear understanding of the existing situation and genuine needs and desires of the target group.

The outputs that are envisaged to serve the project purpose, i.e., "Teaching on the basic education level is effectively carried out" are summarized below:

- Teaching and learning materials are completed and provided.

- Teachers are able to use diverse (project, non-project and non-formal) materials.

- Out-of-school children and adults acquire and make use of Mother and Child Health $(\mathrm{MCH})$, literacy skills and knowledge.

- Community is mobilized to increasingly accept responsibilities for the education of their children.

- Management is strengthened to preserve project know-how for future educational interventions.

Additionally, under the World Bank component, the project implements activities based on the following results:

1. Access to basic education is provided and improved for refugees living in remote areas.

2. The capacity of women and vulnerable persons in literacy, $\mathrm{MCH}$ and vocational education is improved through the NFE component, which will lead to women empowerment.

3. The quality of education of selected middle and secondary schools is improved through an integrated teacher training programme.

4. Improving the quality of teaching in self-help schools. 


\section{THE ORGANIZATION}

BEFARe has three main organizational sections.

1. Central Services
a) External Affairs and Donor Relations
b) General Services and Administration
c) Internal Support

2. Formal Education (FE)
a) School Management
b) Resource and Training
c) Community Participation and Development

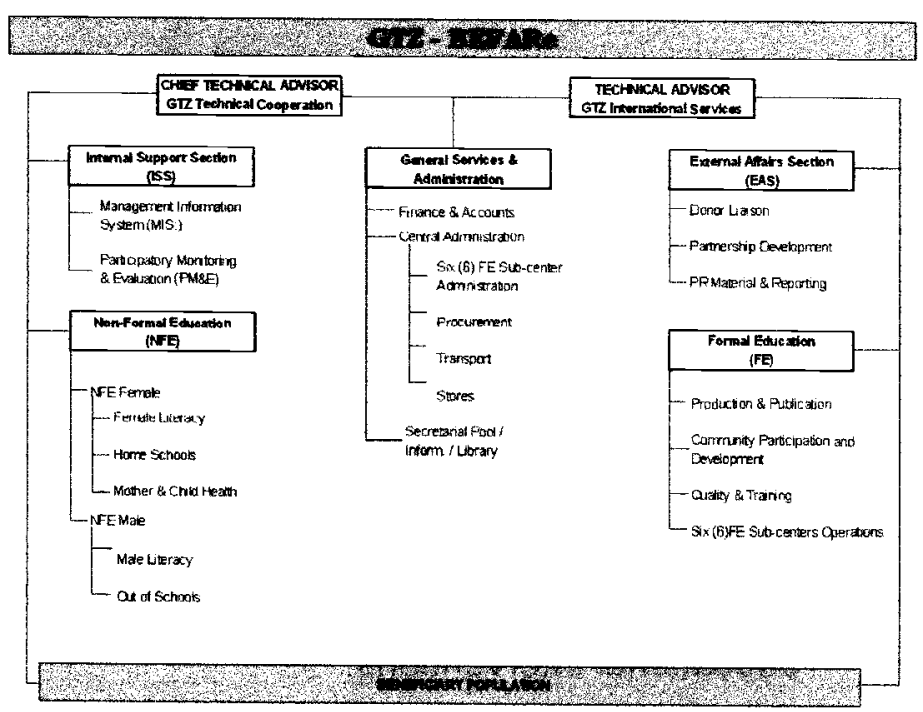

3. Non - formal Education (NFE)
a) Mother and Child Health Program (MCH)
b) Literacy (male and female)
c) Home Schools (boys and girls)

\section{CENTRAL SERVICES}

\section{a) External Affairs and Donor Relations}

The project's External Affairs and Donor Relation component is responsible for coordination and cooperation with other national and international and donor agencies, NGOs and government organizations like CAR, SAFRON, UNHCR, DFID, World Bank etc. Contacts with partner agencies, including representation of the project are the responsibilities of the External Affairs and Donor Relations. 


\section{b) Administration and Finance}

The administrative and financial affairs of the project are the responsibilities of this section. All administrative issues pertaining to the smooth implementation of project actvities are handled by an administrator at the centre and 5 administrators at the sub-center level. Administrative tasks are the maintenance of sub-centres, repairs of vehicles, distribution of textbooks/materials, payment of incentives/salaries etc.

Similarly the section is responsible for the overall financial management of the project like book keeping, salaries, procurement, auditing etc. The Finance Manager and his team ensure the financial management of the programme through regular auditing services in accordance with the German Federal Audit Rules as well as with standards of UNHCR, DFID and, more recently, the World Bank.

\section{c) Internal Support}

The function of this section is to track quantitative as well as qualitative aspects of the project activities through participatory means.

This section has two departments: $\quad: \quad \therefore$

- Management Information System (MIS)

- Participatory Monitoring and Evaluation (PM\&E)

The MIS records and tracks all the quantitative facts and figures, recording project planning and implementation data. It is equipped with computerized databases. The MIS facilitates smooth flow of data through the project at different levels and at different geographical regions. This department also facilitates the incentive and material distribution process, store management, school and per- 
sonnel profiles. It supports the project management in planning and decision making by providing timely, accurate and concise information.

The PM\&E department is responsible for managing a fully functional learning group structure through the whole project and to institutionalize participatory and learning culture at all levels. It also initiates the smooth flow of qualitative aspects of the quantitative figures collected by MIS system. It encourages participation of the primary stakeholders by establishing learning groups at the field level aiming at the empowerment of the beneficiaries. The empowerment of the target group will result in the sustainability of the project.

\section{FORMAL EDUCATION}

\section{a) School Management}

The major task of the project, in addition to administrative management, is the provision of educational support and enhanced supervision and monitoring of 320 primary schools having an enrollment figure of more than 110,000 students (out of which almost 35,000 are giris) and the

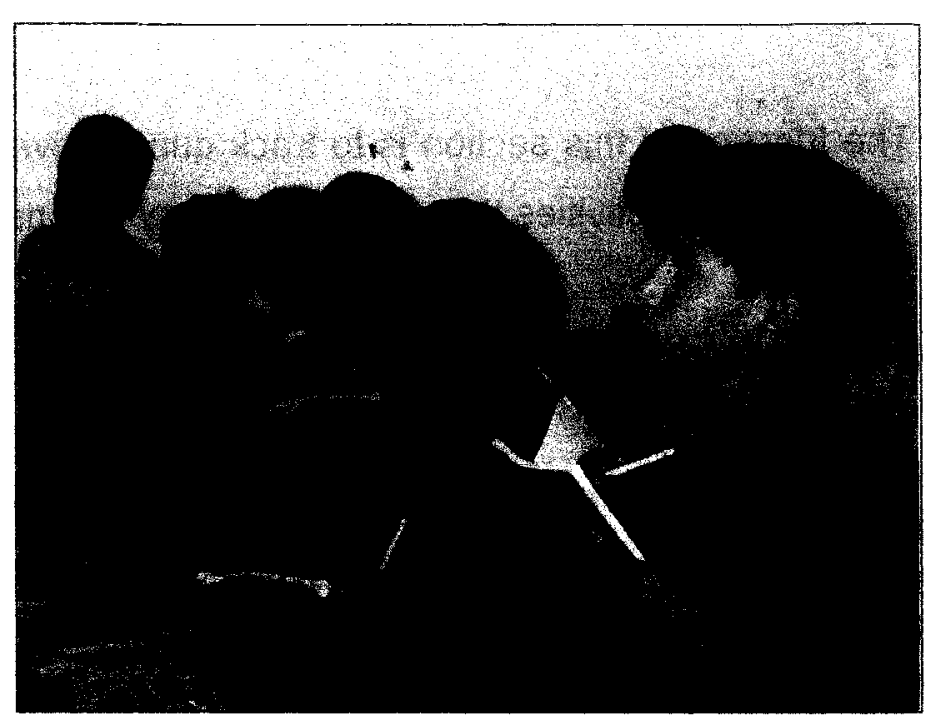
training of teachers 
b) Resource and Training

The project trains about 2,700 teachers (out of which $\mathbf{5 8 0}$ are females) at the primary school level, who are introduced to apply child centered teaching / learning materials in Pashtu and Mathematics and also enable teachers to use manual, guides and teaching aids properly. These teaching materials and lesson plans help the teachers to improve their classroom teaching, which in return help the students to learn more effectively.

In order to improve teaching / learning capabilities, Formal Education provides:

- Training for 21 Master Trainers (MTs) and 86 Field Education Supervisors (FES) whose main responsibilities are to give pedagogical guidance to all the 2,700 teachers.

- Evaluation of FES's monitoring and supervision.

- On the job training to teachers and monitoring of students abilities and activities.

- Training of teachers.

Formal Education is also responsible.under the World Bank component for the training requirements of around 400 teachers of the selected middle and secondary schools including the targeted 250 teachers of the self help schools.

Furthermore, it also provides training to multiplicators of other agencies who use BEFARe's material. They are UNHCR schools in Baluchistan, AG BAS-Ed, Care International, Save the Children (US), Swedish Committee and several other NGOs working inside Afghanistan. 
c) Community Development:

The Community Development and Participation Section has been established to encourage and motivate the participation of the target communities in project related educational activities. This section emphasizes the improvement and


expansion of the project programme as well as the transfer of knowledge on organizational development to the communities. The structure of the Community Development Section has been designed according to the needs and resources of the Afghan community keeping in view the traditional values and the present situation of Afghan refugees. Organizational development has been designed in the context of administrative, economic and socio-psychological system of Afghan refugees, so that the communities should accept it as their traditional system and not as a western approach. This has enabled the project to obtain and record constructive results in the spheres of development of training material, identification of human resources, community motivation, community organization, training, monitoring and evaluation etc.

\section{NON-FORMAL EDUCATION}

\section{a) Mother and Child Health ( $\mathrm{MCH}$ ) Programme}

This programme offers knowledge to females regarding health issues, i.e. mother and child heath, children's prenatal provisions, prevention of children mortality, child growth, nutrition and environmental health etc. The course also includes all 
the appropriate knowledge regarding good-health, problems of infertility, diet, hygiene, warning signals during pregnancy, procedures for a safe and healthy child birth, breast-feeding, protection of a child against common fetal diseases and child development. The whole course is arranged in 21 separate sequences and its messages, provisions and directions have been recorded in dialogue form in cassettes.

Since the start of MCH courses, more than 80,000 women have been reached. Dari language version of the $\mathrm{MCH}$ course is also available to cover the nonPashtu speaking target group, to further widen the scope of these courses

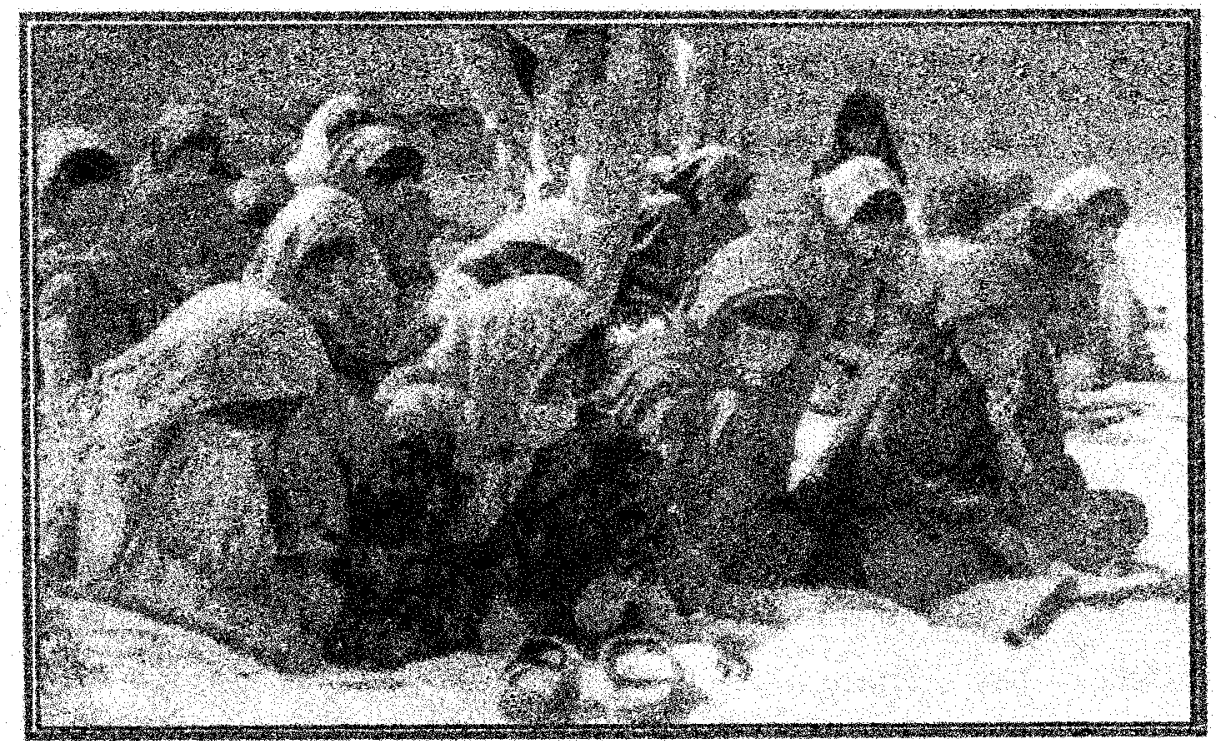

\section{b) Lineracy Programme}

The project is actively engaged in running Pashtu and Dari literacy courses for males and females, which will be crucial for the successful rehabilitation of Afghanistan since there is a greater need for literate people than ever before. The aim of the literacy programme is to enable the graduates of the complete phase to read, write, calculate and understand the simple intents of daily life. By the end 
of $2001,59,000$ participants have successfully passed the literacy courses (out of the total, 22,000 are females).

The literacy courses are conducted in the homes that are nominated by the residents of the camps. A Pashtu Literacy Primer with an accompanying set of charts has been produced for the teaching on the first level. The Arithmetic Primer is introduced on the second level to provide the participants the basic knowledge of numeracy and simple calculations. The Reader Level is followed for practicing the newly acquired skilts on the third level, having wo separate versions for males and females.

In addition to the adult literacy courses, the project has also initiated literacy classes for "out of school" children (boys \& girls) in the form of "Home Schools". These classes are introduced for those boys and girls who "dropped out" or are too young to be admitted in the adult literacy courses and too old to be enrolled in the primary schools. These classes provide a link between the formal and non-formal education as these courses are offered to the participants who are able to complete formal education

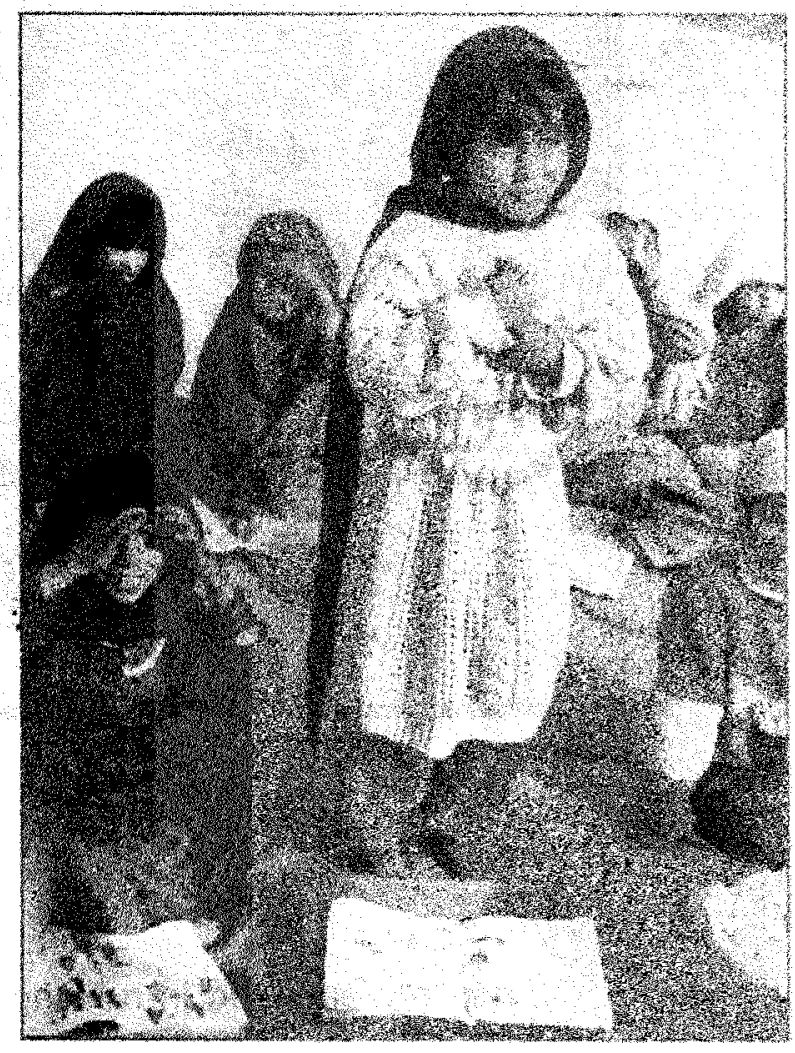
upto grade 4 only in 24 month duration in a non-formal education envitonment. These courses are very popular among the Afghans on both sides of the border. Till date 22,000 children $(5,500$ girls) have successfully passed the home school courses. 
Non-Formal Education is also responsible under the World Bank component for initiating capacity building activities for 5,000 women and vulnerable population through informal and vocational education programmes.

\section{PRODUCTION OF TEACHING AND LEARNING MATERIAL}

BEFARe has developed its curriculum for formal and non-formal basic education based on the criteria resulting from:

- Determination of goals.

- Selection of educational objectives.

- Selection of contents to be learned.

- Selection of teaching / learning strategies.

- Production of instructional materials.

- Organization of materials into courses of studies.

- Testing of new materials.

- Revision of materials on the basis of testing results.

Instructional materials are produced on the basis of a child - centered methodology and are implemented on the following levels:

\section{Formal Education}

- Textbooks, aid materials and teacher guides, Pashtu and Mathematics grades $|-\mathrm{V}|$

- Islamyat, aid materials and teacher guide III. 


\section{Non-Formal Education}

Mother and Child Health $(\mathrm{MCH})$ programme:

- MCH Manual

- Flip Charts

- Audio cassette recordings

Adult literacy programme (male and female):

- Primer: Pashtu and Dari (level 1 with teacher's guide)

- Mathematic: Pashtu and Dari (level 2 with teacher's guide)

- Male Reader: Pashtu and Dari

- Female Reader: Pashtu And Dari

- Charts, word cards, etc.

Messages concerning Islamic values, peace education, cooperation, environment, health, economy, agriculture, drug awareness, mine awareness, cultural heritage, literature, human rights etc. are incorporated in the teaching material in addition to development of necessary skills in language and Mathematics.

\section{AFGHAN GERMAN BASIC EDUCATION (AG BAS-ED)}

The demand to initiate programs and educational activities inside Afghanistan necessitated the project to establish and assist $A G$ BAS-Ed as an independent NGO to contribute to the educational rehabilitation of Afghanistan.

AG BAS-Ed transfers GTZ-BEFARe's multi-year know-how in the area of formal and non-formal educationin four provinces of Afghanistan namely Ningrahar, Laghman, Kunar and Khost. Regular contact is maintained with AG BAS-Ed and 
areas of mutual cooperation and coordination are explored to provide educational support to the Afghans either through the NGO or directly by GTZ.

\section{FUTURE PROSPECTS AND CHALLENGES}

A constant and intensified cooperation and liaison has been established with various organizations such as UNHCR, World Bank, DFID, UNESCO, Swedish Committee, Care International, Save the Children Fund (US), SOS/PG Belgium, ORA and other local and international NGOs using BEFARe's teaching and learning materials.

Similarly, keeping in view the requirements for the future and the growing recognition, the project needs to review and further improve the means in which it has to respond to the expanding complex emergencies and developments. Exclusive packages on vocational education and skills training, HIVIAIDS, family health and mine awareness have also been complementarily introduced to the target group. It is envisaged that by the introduction of these preclusive packages, the project will not only be contributing to the efforts of UN in the reconstruction and rehabilitation of Afghanistan but at the same time assisting in the repatriation process of Afghan refugees to their homeland.

The project is presently equipped and geared to take over additional responsibilities of implementing educational programmes on behalf of other agencies and international donors. It has the capacity, the infrastructure and the experience to embark on any ambitious educational programme both in Pakistan and Afghanistan.

\begin{tabular}{ll}
\hline For further information please contact: \\
Chief Technical Advisor (CTA): & Holger Munsch \\
Technical Adviser: & Jurgen Wintermeier \\
Postal Address: & University P.O. Box \# 1481, Peshawar, PAKISTAN \\
Telephone: & $++92(91) 480631$ or 42955 \\
Fax: & $++92(91) 841047$ \\
e-mail: & befare@brain.net.pk and befare@yahoo.com \\
Address: & 8 Tatara Rd, Rahatabad, Peshawar, PAKISTAN
\end{tabular}


School Activity Aroa \& Infrastructure

\begin{tabular}{|c|c|c|c|c|c|c|c|c|c|c|c|c|c|c|c|c|}
\hline \multirow{3}{*}{ Sub-Centers } & \multirow{3}{*}{$\begin{array}{l}\text { No of } \\
\text { Camps }\end{array}$} & \multirow{2}{*}{\multicolumn{3}{|c|}{ No of Schools }} & \multicolumn{12}{|c|}{ No of Rooms and Sections } \\
\hline & & & & & \multicolumn{2}{|c|}{ Grade 1} & \multicolumn{2}{|c|}{ Grade 2} & \multicolumn{2}{|c|}{ Grade 3} & \multicolumn{2}{|c|}{ Grade 4} & \multicolumn{2}{|c|}{ Grade 5} & \multicolumn{2}{|c|}{ Grade 6} \\
\hline & & Girls Schools & Boys Schools & $\begin{array}{l}\text { Co-Edu. } \\
\text { Schools }\end{array}$ & Rooms & Sections & Rooms & Sections & Rooms & Sections & Rooms & Sections & Rooms & Sections & Rooms & Sections \\
\hline Abbottabad & 30 & 9 & 29 & 6 & 82 & 127 & 57 & 95 & 53 & 82 & 42 & 53 & 38 & 42 & 34 & 38 \\
\hline 3unnu & 27 & 8 & $\therefore \quad 24$ & 16 & 52 & 71 & 44 & 53 & 35 & 46 & 32 & 41 & 24 & 37 & 19 & 28 \\
\hline tungu (Thal & 42 & 10 & 36 & 8 & 82 & 99 & 83 & 88 & 71 & 72 & 62 & 64. & 55 & 58 . & 39 & 42 \\
\hline Mardan & 16 & 13 & 33 & 3 & 79 & 110 & 68 & $79:$ & 55 & 70 & 48 & 56 & 42 & 49 & 32 & 39 \\
\hline Peshawar & 20 & 14 & 40 & 8 & 120 & $197:$ & 95 & 155 & 85 & 127 & 77 & 97 & 55 & 78 & 39 & 65 \\
\hline Timergara & 28 & 19 & 18 & 19 & 64 & 96 & 65 & 84 & 64 & 82 & 61 & 75 & 52 & 63 & 44 & 47 \\
\hline Shalman & 2 & 1 & 1 & 5 & 29 & 40 & 2 & 10 & 1 & 6 & - & 5 & - & 1 & - & 1 \\
\hline Total & 165 & 74 & 181 & 65 & 508 & 740 & 414 & 564 & 364 & 485 & 322 & 391 & 266 & 328 & 207 & 260 \\
\hline
\end{tabular}

\begin{tabular}{|c|c|c|c|c|c|c|c|c|c|c|c|c|c|c|c|c|}
\hline \multirow{4}{*}{ 3ub-Centers } & \multirow{4}{*}{$\begin{array}{l}\text { Branch } \\
\text { Schools }\end{array}$} & \multirow{4}{*}{$\begin{array}{c}\text { After Noon } \\
\text { Shift }\end{array}$} & \multirow{4}{*}{$\begin{array}{l}\text { No of } \\
\text { SMCs }\end{array}$} & \multicolumn{11}{|c|}{ Teaching and School Staff } & \multirow{3}{*}{\multicolumn{2}{|c|}{$\begin{array}{l}\text { Auxiliary Staff } \\
\text { (Chowkidar) }\end{array}$}} \\
\hline & & & & \multicolumn{5}{|c|}{ Head Teachers } & \multicolumn{5}{|c|}{ Teachers } & \multirow{3}{*}{$\begin{array}{c}\text { Total } \\
\text { Teaching } \\
\text { Staff }\end{array}$} & & \\
\hline & & & & \multicolumn{2}{|c|}{ Afghan } & \multicolumn{2}{|c|}{ Pakistani } & \multirow{2}{*}{ Total H.T. } & \multicolumn{2}{|c|}{ Afghan } & \multicolumn{2}{|c|}{ Pakistani } & \multirow[b]{2}{*}{ Total } & & & \\
\hline & & & & Male & Female & Male & Female & & Male & Female & Male & Female & & & Male & Female \\
\hline Abbottabad & 1 & 3 & - & 33 & 7 & 1 & 3 & 44 & 267 & 51 & 112 & 21. & 451 . & 495 & 59 & 1 \\
\hline Bunnu & 1 & - & 40 & 40 & 2 & - & 6 & 48 & 98 & 6 & 72 & 20 & 196 & 244 & 53 & $*$ \\
\hline tungu (Thal) & 4 & - & 54 & 44 & 7 & 1 & 2 & 54 & 195 & 30 & 106 & 22 & 353 & 407 & 64 & 2 \\
\hline Mardan & 2 & 1 & 42 & 34 & 5 & 4 & 6 & 49 & 180 & 26 & 127 & 36 & 369 & 418 & 69 & $\therefore$ \\
\hline Peshawar & 7 & 17 & 62 & 47 & 8 & 1 & 6 & 62 & 373 & 139 & 139 & 42 & 693 & 755 & 98 & 2 \\
\hline limergara & - & 7 & 54 & 42 & 11 & - & 3 & 56 & 197 & 62 & 92 & $43:$ & 394 & 450 & 71 & $\underline{2}$ \\
\hline shalman & - & - & - & 6 & 1 & . & - & 7 & 46 & 6 & 9 & - & 61 & 68 & 8 & - \\
\hline Total & 15 & 28 & 252 & 246 & 41 & 7 & 26 & 320 & 1,356 & 320 & 657 & 184 & 2,517 & 2,837 & 422 & 7 \\
\hline & & & & & & & & & & & & & & & Total & 429 \\
\hline
\end{tabular}

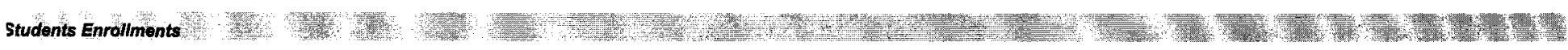



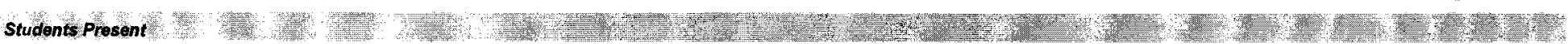

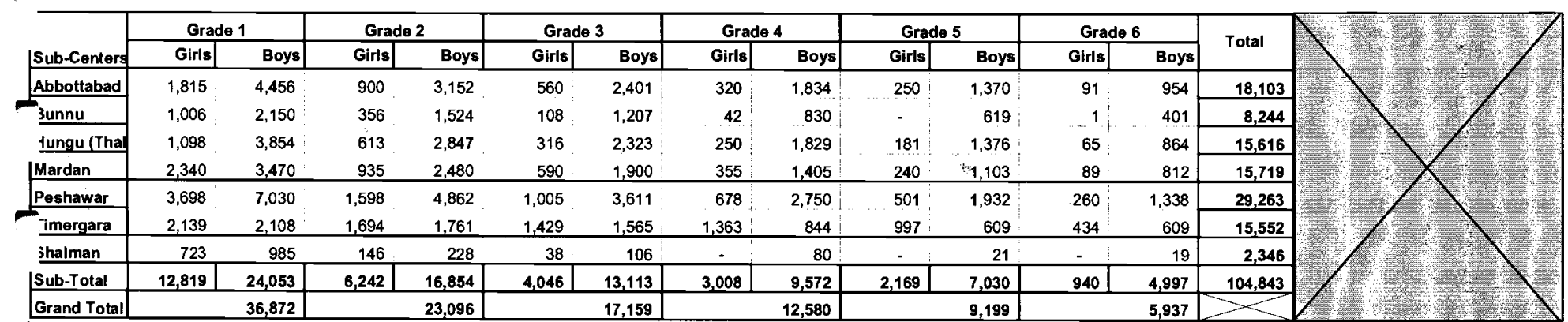

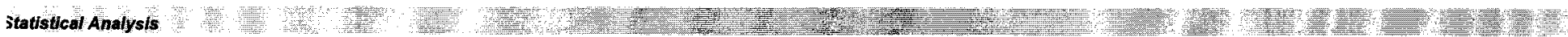

\begin{tabular}{|c|c|c|}
\hline $\begin{array}{l}\text { jub- } \\
\text { 2enters }\end{array}$ & $\begin{array}{l}\text { Teachers } \\
\text { Student } \\
\text { Ratio }\end{array}$ & $\begin{array}{l}\text { Percentage } \\
\text { of Present } \\
\text { Students }\end{array}$ \\
\hline Abbottabad & $1: 37$ & $97.98 \%$ \\
\hline Bunnu & $1: 36$ & $93.66 \%$ \\
\hline lungu (Tha: & $1: 40$ & $96.02 \%$ \\
\hline Mardan & $1: 39$ & $96.81 \%$ \\
\hline Peshawar & $1: 39$ & $99.67 \%$ \\
\hline Timergara & $1: 37$ & $92.63 \%$ \\
\hline Shalman & $1: 35$ & $100.00 \%$ \\
\hline iotal & $1: 38$ & $96.83 \%$ \\
\hline
\end{tabular}

Gender Wise Percentage of Enrollment and attendance
\begin{tabular}{|l|r|r|r|r|}
\hline \multirow{2}{*}{ Gender } & \multicolumn{1}{|c|}{ Total No of Students } & \multicolumn{2}{|c|}{ Total Percentage } \\
\cline { 2 - 5 } & Enrolled & Present & Enrolled & Present \\
\hline Girls & 29,725 & 29,224 & $27.5 \%$ & $98.3 \%$ \\
\hline Boys & 78,549 & 75,619 & $72.5 \%$ & $96.3 \%$ \\
\hline Total & 108,274 & 104,843 & $100.0 \%$ & $96.8 \%$ \\
\hline
\end{tabular}

Gender Distribution of Student Enrolled

\begin{tabular}{|l|r|}
\hline Total Girls Students & $\mathbf{2 9 , 7 2 5}$ \\
\hline Total Boys Students & 78,549 \\
\hline Total Students (Both Gender) & 108,274 \\
\hline
\end{tabular}

\begin{tabular}{|c|c|c|c|c|c|c|}
\hline Grades & Girls & Percent & Boys & Percont & Total & Percont \\
\hline Grade 1 & 13,233 & 15\% & 24,735 & $31 \%$ & 37,968 & $35 \%$ \\
\hline Grade 2 & 389 & $21 \times$ & 17,330 & $22 \%$ & 23,719 & $22 \%$ \\
\hline Grade 3 & 4,143 & 148 & 13,531 & 172 & 17,674 & $16 \%$ \\
\hline Grade 4 & 2,779 & $8 \%$ & 10,379 & 13\% & 13,158 & $12 \%$ \\
\hline Grade 5 & 2,055 & $=78$ & 7,650 & $10 \%$ & 9,705 & 86 \\
\hline Grade 6 & 1,126 & 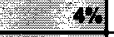 & 4,924 & $6 \%$ & 6,050 & $6 \%$ \\
\hline Total & 29,725 & 10026 & 78,549 & $100 \%$ & 108,275 & $6 \%$ \\
\hline
\end{tabular}




\section{GTZ - BEFARe}

Non-Formal Education Monthly Statistics Report January, 2003.

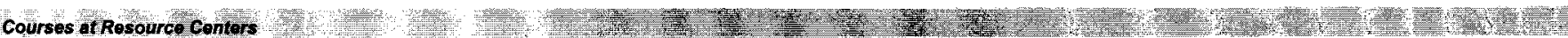

\begin{tabular}{|c|c|c|c|c|c|c|c|c|c|c|c|c|c|}
\hline \multirow{2}{*}{$\begin{array}{c}\text { Resource } \\
\text { centers }\end{array}$} & \multirow{2}{*}{$\begin{array}{l}\text { No. of } \\
\text { camps }\end{array}$} & \multirow{2}{*}{$\begin{array}{c}\text { No. of course } \\
\text { centers }\end{array}$} & \multicolumn{4}{|c|}{ No. of courses } & \multirow{2}{*}{$\begin{array}{l}\text { No. of Co- } \\
\text { Educatlon } \\
\text { courses }\end{array}$} & \multirow{2}{*}{$\begin{array}{l}\text { Resource- } \\
\text { center wlse } \\
\text { courses }\end{array}$} & \multicolumn{2}{|c|}{ No. of shifts } & \multicolumn{2}{|c|}{ Donars } & \\
\hline & & & Girls & Boys & Females & Males & & & Morning & Evening & World Bank & DFID & \\
\hline Abbottabad & 7 & 90 & 33 & 17 & 14 & 19 : & 15 & 98 & 30 & 68 & $55:$ & 43 & \\
\hline Bunnu & $\theta^{\prime}$ & - & - & $=$ & - & - & & - & & & . & - & \\
\hline Hungu (Thall) & 7 & $\cdot 43$ & 7 & 3 & 5 & 14 & 19 & 48 & & 48 & 48 & - & \\
\hline \begin{tabular}{|l|} 
Mardan \\
\end{tabular} & 3 & 17 & 1 & 4 & - & 6 & 6 & 17 & - & 17 & & 17 & 10 \\
\hline Peshawar & 9 & 94 & 33 & 30 & 17 & 15 & 8 & 103 & 10 & 93 & - & 103 & \\
\hline Timergara & 9 & 130 & 33 & 44 & 22 & 25 & 8 & 132 & 2 & 130 & 97 & 35 & \\
\hline Total & 35 & 374 & 107 & 98 & 58 & 79 & 56 & 398 & 42 & 356 & 200 & 198 & \\
\hline
\end{tabular}

Porsonnel

\begin{tabular}{|c|c|c|c|c|c|c|c|c|c|c|c|c|c|}
\hline \multirow{4}{*}{$\begin{array}{l}\text { Resource } \\
\text { centers }\end{array}$} & \multirow{4}{*}{ No. of SMCs } & \multicolumn{11}{|c|}{ Teaching staff } & \\
\hline & & \multicolumn{5}{|c|}{ Home School courses } & \multicolumn{5}{|c|}{ Literacy courses } & \multirow{3}{*}{$\begin{array}{c}\begin{array}{c}\text { Total } \\
\text { teaching } \\
\text { staff }\end{array} \\
\end{array}$} & \\
\hline & & \multicolumn{2}{|c|}{ Afghan } & \multicolumn{2}{|c|}{ Pakistanl } & \multirow{2}{*}{$\begin{array}{c}\text { Total } \\
\text { teachers }\end{array}$} & \multicolumn{2}{|c|}{ Afghan } & \multicolumn{2}{|c|}{ Paklstanl } & \multirow{2}{*}{$\begin{array}{c}\text { Total } \\
\text { teachers }\end{array}$} & & \\
\hline & & Female & Male & Female & Male & & Female & Male & Female & Male & & & \\
\hline Abbottabad & - & 12 & 29 & 8 & - & 49 & 13 & 19 & 9 & - & 41 & 90 & \\
\hline Bunnu & & - & & & - & 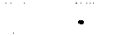 & & t. & & - & ; & $\cdot 1$ & \\
\hline Hungu (Thall) & . & 5 & 22 & - & - & 27 & 5 & 11 & - & - & 16 & 43 & \\
\hline Mardan & - & & 11 & - & - & 11 & 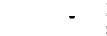 & 6 & - & 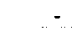 & 6 & 17 & \\
\hline Peshawar & . & - & 40 & 29 & - & 69 & 13 & 15 & - & - & 28 & 97 & \\
\hline Timargara & . & 33 & 52 & - & $\therefore$ & 85 & 22 & 25 & - & - & 47 & 132 & \\
\hline Total & . & 50 & 154 & 37 & . & 241 & 53 & 76 & 9 & - & 138 & 379 & \\
\hline
\end{tabular}

Students Panticlpants Enrollmont

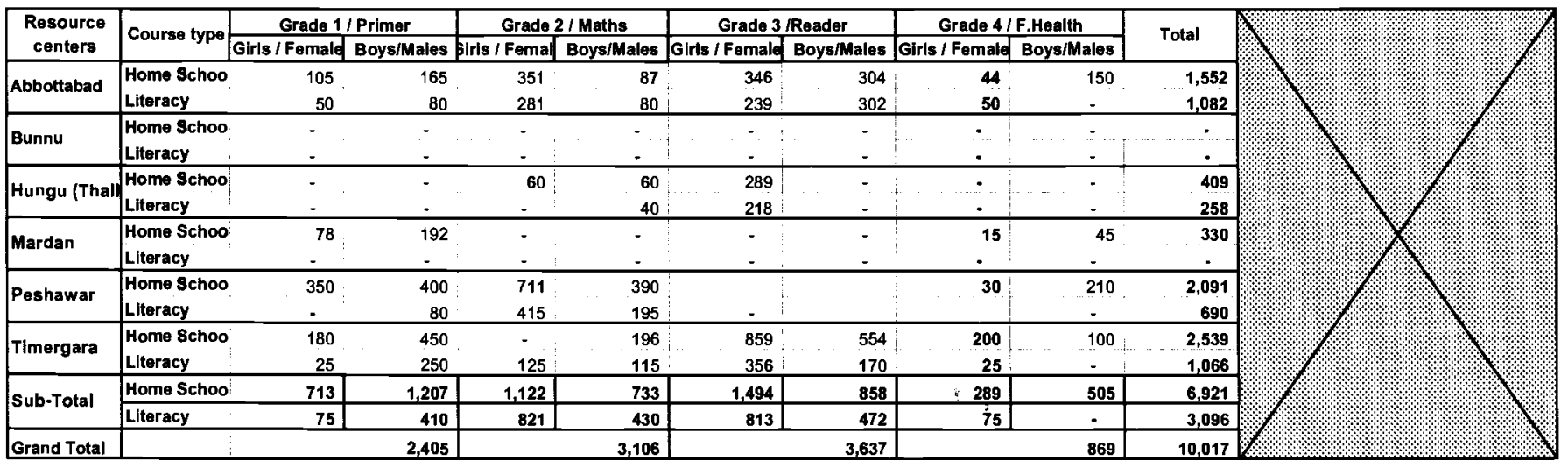

Students Pertclpanta Prosent =

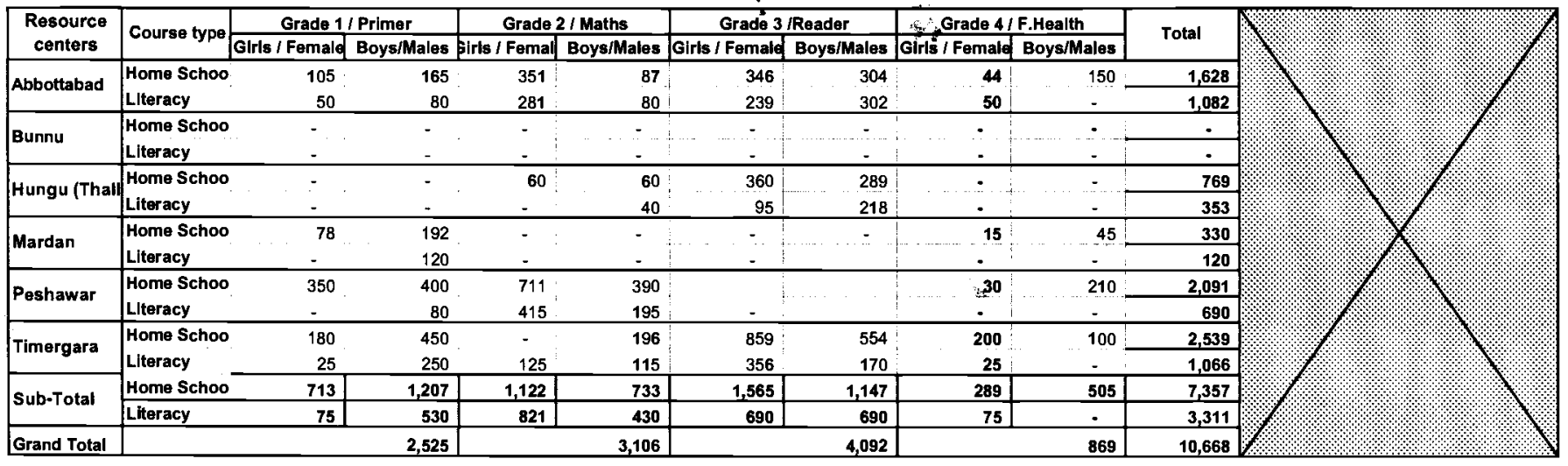

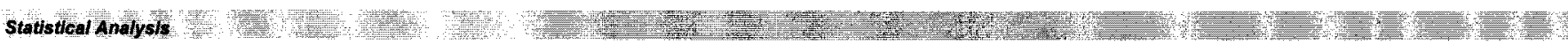

Grade wise Enrolled Student's / Participant's Gender D/stribution

\begin{tabular}{|c|c|c|c|c|c|c|c|}
\hline Grades & & Girls / Female & Porcent & Boys / Male & Porestit: & Total & Pront \\
\hline \multirow{2}{*}{\begin{tabular}{|l|} 
Grade 1/ \\
Primer
\end{tabular}} & Home Schoo & 713 & $20 \%$ & 1,207 & 374 & 1,920 & 34 \\
\hline & Literacy & 75 & 48 & 410 & 312 & 485 & 16 \\
\hline \multirow{2}{*}{\begin{tabular}{|l|} 
Grade 21 \\
Maths
\end{tabular}} & Home Schoo & 1,122 & $31 \%$ & 733 & 229 & 1,855 & $\sqrt{74}$ \\
\hline & Literacy & 821 & $46 \%$ & 430 & 33 & 1,251 & 104 \\
\hline \multirow{2}{*}{\begin{tabular}{|l|} 
Grade 31 \\
Reader
\end{tabular}} & Home Schoo & 1,494 & $41 \%$ & 858 & 26. & 2,352 & $7 \%$ \\
\hline & Literacy & 813 & $66 \%$ & 472 & 86. & 1,285 & 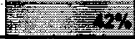 \\
\hline \multirow{2}{*}{$\begin{array}{l}\text { Grade 4/F. } \\
\text { Health }\end{array}$} & Home Schoo & 289 & $6 \%$ & 505 & 10 & 794 & 118 \\
\hline & Literacy & 75 & 18\% & - & 04 & 75 & 26 \\
\hline \multirow{2}{*}{ Total } & Home Schoo & 3,618 & $100 \%$ & 3,303 & 1009 & 6,922 & T) \\
\hline & LIteracy & 1,784 & $100 \%$ & 1,312 & 100 & 3,097 & $=100 x$ \\
\hline
\end{tabular}

\begin{tabular}{|c|c|}
\hline Total girls students in Home Schools & 3,618 \\
\hline Total boys students in Home Schools & 3,303 \\
\hline Total female participants in Literacy courses & 1,784 \\
\hline Total male participants in Literacy courses & 1,312 \\
\hline Total (both gender) & 10,017 \\
\hline
\end{tabular}

\begin{tabular}{|c|c|c|c|c|}
\hline & July & August & Difference & Dropout \\
\hline Girls & 2,865 & 4,258 & $-1,393$ & No \\
\hline Boys & 3,091 & 3,385 & .294 & No \\
\hline Female & 570 & 1,553 & -983 & No \\
\hline Male & 627 & 1,125 & -498 & No \\
\hline Total & 7,153 & 10,321 & $-3,168$ & No \\
\hline
\end{tabular}

Note: Some of the teachers are running more than 1 course. Some time more than 1 courses are also conducted at 1 Course Center. 

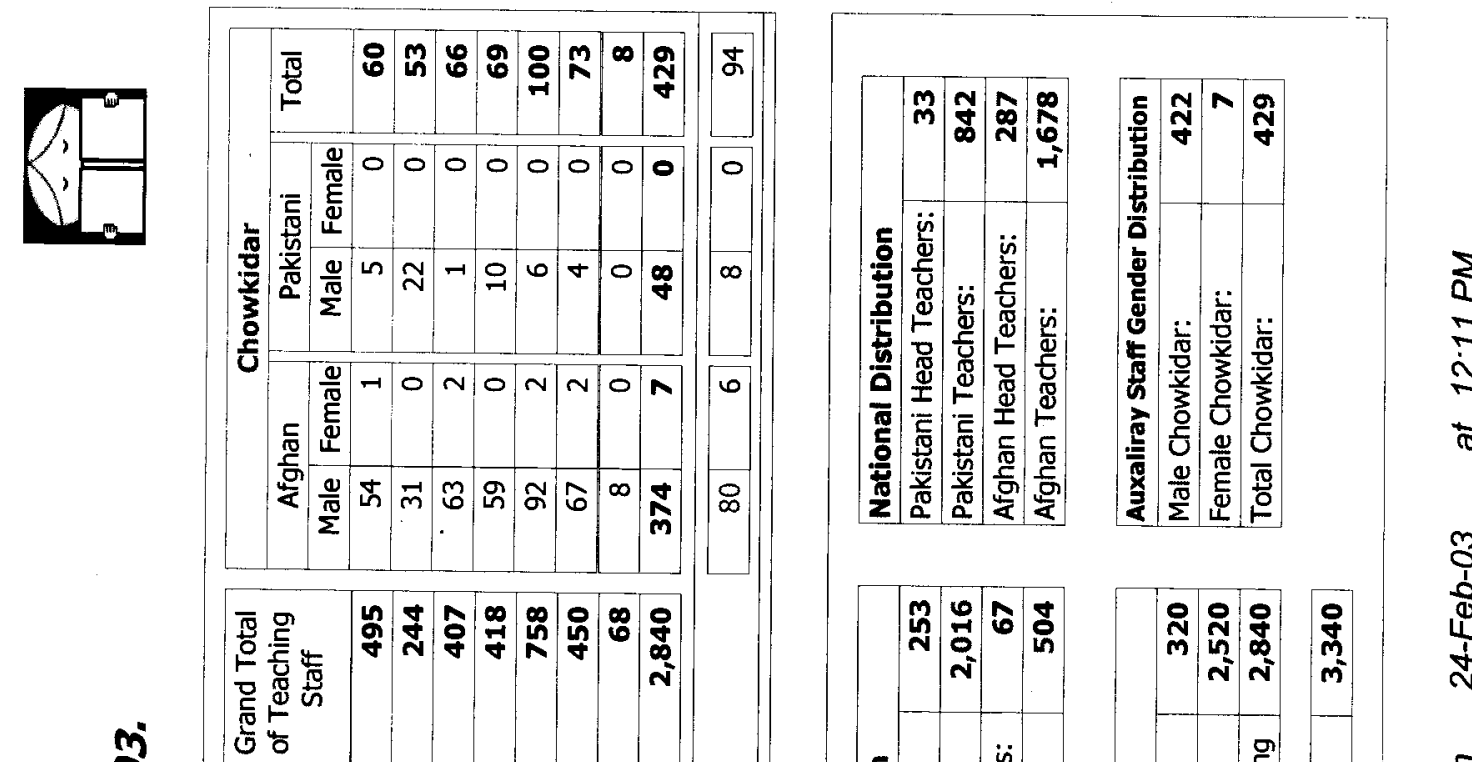

$\stackrel{m}{8}$ 은

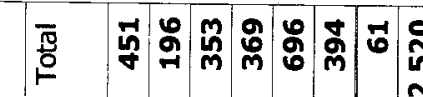

㠃

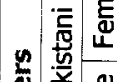

造

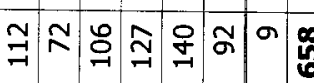
荧

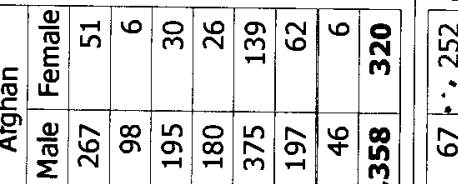

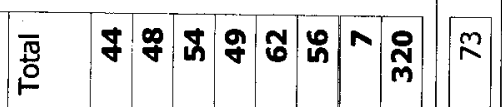

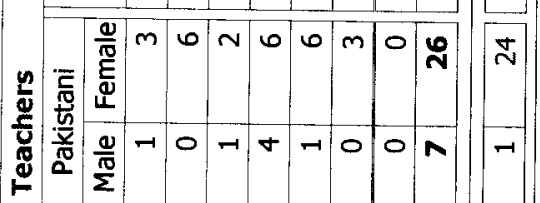

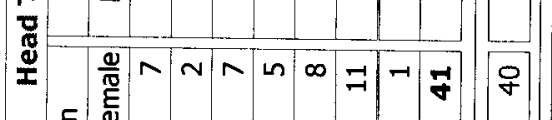
돓

这管
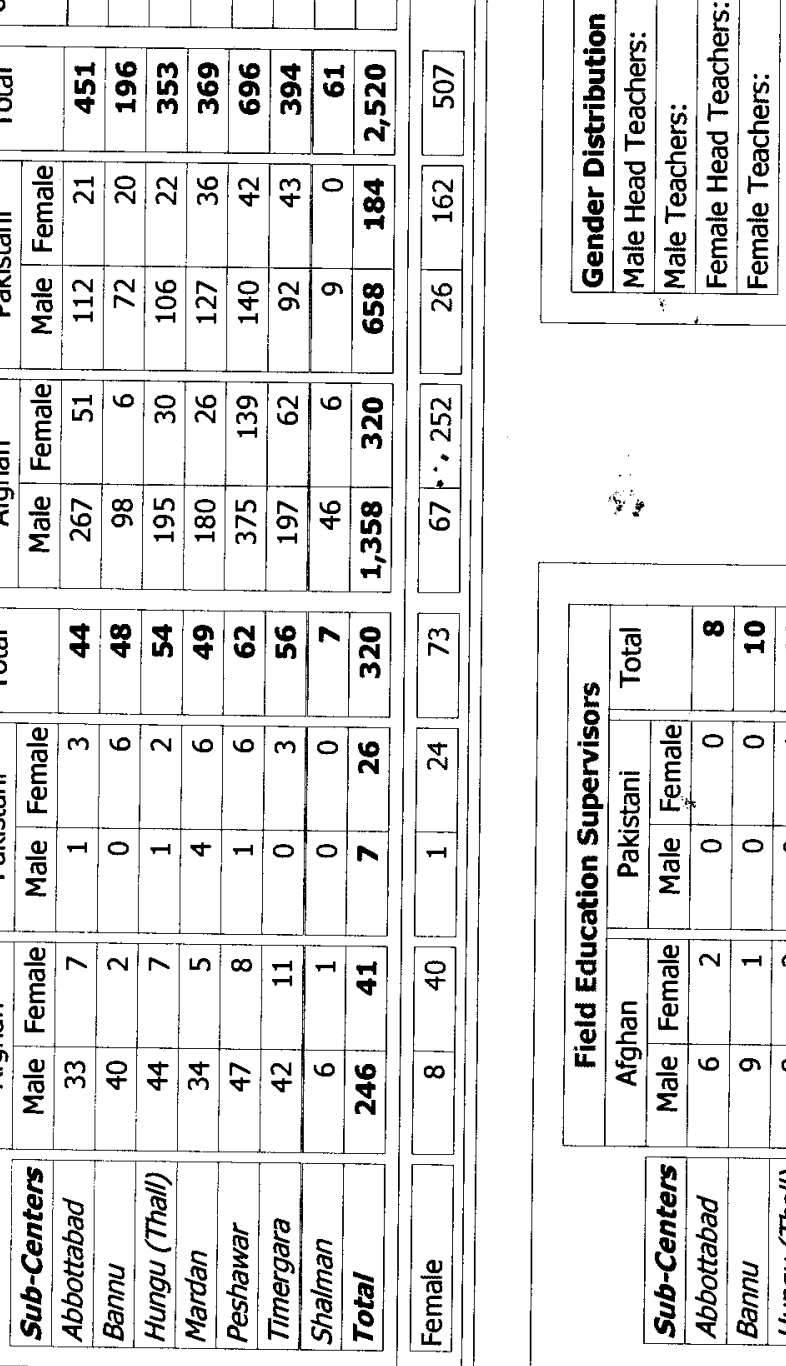

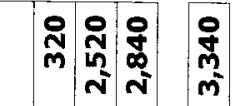

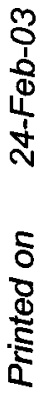

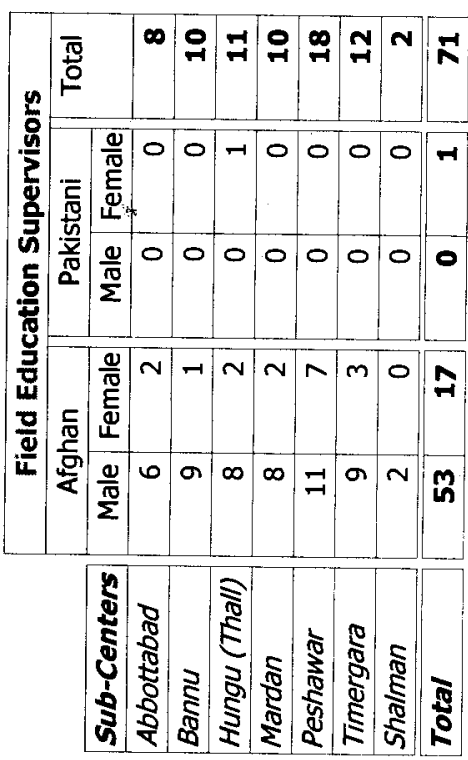


